\title{
Kiss Máté
}

\section{A NORMASZEGÉS ÉS AZ ÚJITÁS KAPCSOLATA}

DOI 10.35402/kek.2020.1.2

\begin{abstract}
Absztrakt
E rövid írásban kísérletet teszek arra, hogy Victor Turner társadalmi dráma elméletét felhasználva elemzem az innovációk mibenlétét, hogyan kapcsolható össze az új létrehozása (legyen az technológia, gondolkodásmód, applikáció, vagy új tudományos módszertan) a turneri normaszegés, törés fogalmával. Az elmélet fóbb pontjainak ismertetése után néhány történeti példa segítségével kontextusba helyezem az újítás, innováció modernitástól független jellemzőit. Majd az információs társadalom korába érkezve, a big data jelensége kapcsán példákon keresztül vizsgálom, mennyiben alkalmazható a turneri elmélet a közelmúlt és a jelen folyamataira. Végül kitekintek az általam leginkább ismert diszciplína ezekre adott válaszára, a digitális antropológiára.
\end{abstract}

\begin{abstract}
In this short text, I attempt to analyze the nature of innovation, using Victor Turner's theory of social drama, how the creation of new (technology, thinking, application, or scientific methodology) can be linked to Turner's thinking about the breaking of norms. After presenting the main points of Turner's theory, I use some historical examples to contextualize the features of innovation which are independent of modernity. Then, in the age of the information society, I examine through examples of the big data phenomenon the applicability of the social drama theory to recent and present processes. Finally, I reflect on the dilemmas posed by this new era, new context to the discipline of cultural anthropology and on one of its response, digital anthropology.
\end{abstract}

\section{Victor Turner társadalmi dráma elmélete}

A társadalmi változás, társadalmi konfliktus egyik legismertebb, s legtöbbet idézett elméleti leírását a kulturális antropológia diszciplínáján belül Victor Turner brit kutató, a szimbolikus antropo- lógia képviselője fogalmazta meg társadalmi dráma elméletében. Szakmájának, választott tudományának szabályait követve, az absztrakt séma felállítását terepkutatás előzte meg az afrikai ndembuknál, s nagyban támaszkodott egy korábbi elméleti munkára, Van Gennep átmeneti rítusokról írott tanulmányára. Turner szintén elemzi a beavatás, és ezzel együtt a társadalmi státus megváltozásának egyéni és társadalmi vonatkozásait is, s ezzel az elméletével rokonítható a társadalmi dráma gondolata, melyet alkalmazhatónak tart középkori izlandi sagák értelmezésén keresztül forradalmak vizsgálatán át, politikai botrányok elemzéséig (például a Watergate-ügy esetét).

Turner a társadalmi dráma absztrakt modelljén belül négy különálló, egymásból következő részt, felvonást határoz meg. A folyamat első elemeként meghatározza az egész folyamatot elindító mozzanatot, a törést, ,az általános, normák által müködtetett társadalmi interakciók megszegését" ${ }^{1} \mathrm{ami}$ megtörténhet személyek vagy csoportok között, afrikai faluközösségekben, de éppen úgy egy európai ország politikai mozgásaiban is. A normaszegés aktusának hozzárendelését az újhoz, a változáshoz és változtatáshoz érdemes összevetni Hannah Arendt történeti-filozofikus forradalomelemzésével, amiben szintén egyesíti a kezdetet, az alapítást, az új létrehozását az erőszakkal, a bűnnel, a törvényszegéssel. ${ }^{2}$ (Kiemelendő különbségtétel, hogy míg Arendt mindhárom fogalmat alkalmazza, addig a turneri elmélet hangsúlyozza a társadalmi drámát elindító mindenkori normaszegés altuisztikusságát, megjegyezve, hogy a bűnként definiált cselekvés ezzel szemben szükségszerűen egoisztikus).

A második fázis a krizis, illetve a krízis mélyülése, (legalábbis abban az esetben, ha nem sikerült a törést „begyógyítani”, a konfliktust körbezárni, eszkalálódását megakadályozni). Ekkor a felszínre bukkannak, a nyilvánosság terébe kerülnek az addig magánszférában, a felszín alatt működő ellentétek, viszályok, a közösség tagjainak szükségszerűen állást kell foglalnia a felek között. Így a krízis momentuma minden esetben fordulópontként jelenik meg, fenyegetést és veszélyt rejt magában azzal, hogy

1 Turner 1974:38

2 Arendt 1991:49 
„minden esetben magában hordoz liminális jellemzőket, jelleget, hiszen küszöbként értelmezhető a társadalmi folyamat két, többé-kevésbé stabil fázisa között". ${ }^{3}$

A helyreállító akciók szakaszában, a krízist megélő társadalom vagy közösség vezetői, reprezentatív személyiségei kísérletet a konfliktus erejének mérséklésére. Az ezt célzó cselekvés, cselekvéssor lehet formális, vagy informális, innovatív, vagy intézményesített jellegű, ebből következően efféle aktusként interpretálható a nem hivatalos tárgyalás, közvetítés kísérlete éppúgy, mint a jogrendszer mechanizmusának igénybevétele. Így a rend helyreállítására vonatkozó kísérlet magába foglalhat mind pragmatikus gyakorlatokat, mind szimbolikus tetteket, vagy ezek keveredését. Amennyiben ezek elbuknak, értelemszerủen következik a visszacsúszás a válságos állapotba. „Ezen a ponton lehetségessé válik a nyers erő bevetése, az erőszak alkalmazása, ami változatos módokon történhet $[\ldots]$ ". ${ }^{4}$

A turneri elméleti konstrukció negyedik, utolsó eleme, a dráma záró felvonása pedig kétféle úton haladhat. Az utolsó szakasz egyik lehetséges kimenetele a reintegráció lehet, a másik kimenetel pedig a szakadás nyilvános elismerése. Bármelyik lehetőség is következik be, az elmélet alapján az bizonyos, hogy a törés, normaszegés előtti állapot nem rekonstruálható teljességgel, a társadalmi rend valamilyen formában szükségképpen módosul, változik. Megváltozhatnak a legitimáció módozatai, egyes technikák, ugyanakkor alapvető normák, azok által kijelölt célok és viszonyok, szokások érintetlenül maradhatnak.

A koncepció hatását és hatékonyságát jelzi, hogy Tiszaeszlári dráma című társadalomtörténeti monográfiájában Kövér György is idézi mint magyarázóerővel bíró, inspiráló elméletet, ami segíthet annak megértésében, mi is történt, történhetett a tizenkilencedik század végén egy magyar faluban, mely események végül a vérvád felbukkanásában, bírósági ügyben, s országossá váló politikai (s adott esetben fizikai) küzdelemben csúcsosodtak ki. ${ }^{5} \mathrm{Ha}-$ sonlóképpen Hofer Tamás a magyar rendszerváltás eseményeinek menetének, tömegrendezvényeinek hatásának vizsgálatára alkalmazta, hasznosította a turneri gondolatmenetet. ${ }^{6}$

\footnotetext{
3 Turner 1974:39

4 Turner 1974:41

5 Kövér 2011:11

6 Hofer 1992:29-51
}

\section{Innováció és normaszegés}

A továbbiakban kísérletet teszek arra, hogy társadalmi dráma-elmélet fázisait, vagy egy-egy partikuláris mozzanatát olyan területre alkalmazzam, ahol a változás jelensége éppen úgy megjelenik, mint egy ndembu falu viszályaiban, vagy egy izlandi hőstörténetben megénekelt vérbosszúk rendszerében. A különbség az előbbi példákhoz képest, hogy az információs társadalom, a big data jelensége okozta változások, a lineáris és exponenciális gondolkodásmódok és szervezetek mibenléte és konfliktusa sokkal nehezebben körülhatárolható rendszer, társadalmi egység, mint egy klánok közötti háborúskodás, egyesült államokbeli elnöki botrány, vagy a közép-európai államok rendszerváltásai.

Ennek okán szükségesnek érzem lehatárolni a vizsgálódás körét, így fókuszba az innovációk kérdését helyezem, a turneri elméletből pedig a normaszegés, -törés aktusán keresztül próbálom értelmezni az újítások megjelenését, kigondolását. $\mathrm{Az}$ innováció fogalmát Holczer Márton az információs társadalom kontextusában a következőképpen definiálja: „[...] a meglevő információk és tudások újszerű összekapcsolása, alkalmazása, illetve új ismeretek és tudások előállítása [...].7 Megkülönböztet kis és nagy innovációkat, melyek közül az előbbi tehát azoknak a problémáknak a megoldását jelenti, ahol van elképzelés az elérni szándékozott eredményről, célról, éppen csak az odavezető út kérdéses. Így ezt a műveletet Holczer a rejtvényfejtéssel rokonítja. Míg a nagy innováció esetében valamilyen gyökeresen új létrehozás történik, nem az eleve meglevő módszerek finomítása, hanem egy olyan újítás, amiről kezdetben nem is tudható milyen hatást gyakorol, milyen értéke lehet.

Efféle innovációkat természetesen nem kizárólag a modernitás korában, az információs társadalom közegében találhatunk. Ilyen alapvető változtatásokat, új utakat, társadalmakat, vagy történelmet átformáló gondolati újításokat találhatunk földrésztől, korszaktól függetlenül. Oda Nobunaga hadvezér Japán tizenhatodik századi (első, tehát nem maradéktalanul sikeres) egyesítője, a hadakozó fejedelmek polgárháborús korában egy alapvető katonai, taktikai változtatással szétzúzta ellenfelét. A muskéták használata a japán ütközetekben már nem volt újdonság 1575-ben, köszönhetően a portugál kereskedőknek, ám alkalmazásuk nem volt problémamentes.

7 Holczer 2007:94 
Működésüket befolyásolhatta az időjárás, az újratöltés hosszúsága miatt ezeket az egységeket elsöpörhette egy lovasroham, ahogyan azt Nobunaga ellenfele Takeda Katsuyori is tervezhette a nagashinói csata előtt. A Takeda nehézlovasságnak egy sortüz után is minden addigi tapasztalat szerint meg kellet volna semmisítenie a könnyű páncélzatú muskétás egységeket. Ám Nobunaga kigondolt innovációja, hogy több sorban állítja fel tüzfegyverrel harcoló egységeit, majd váltott sortűzzel, és felállított akadályokkal lehetetlenné teszi a lovasság előretörését saját haderejéig, megtörve a lovasrohamot, megnyerte számára a csatát. ${ }^{8}$ A Takeda klán pedig elvesztette seregének derékhadát és így nem jelentett többé akadályt Japán egyesítését áhító hadúr előtt. Látható, hogy a technológia, jelen esetben a muskéta és az általa képviselt tűzerő, már jelen volt Japánban, az esélyek megfordítása egyáltalán nem az eszközök meglétén múlt, hanem azok kreatív felhasználásán, az addig használt módszer radikális megváltoztatásán, avagy az új gondolat megszületésén.

A társadalmi változás, innováció egy másik antropológiai leírása, az előbbi katonai, taktikai újításhoz képest sokkal kevésbé körülhatárolható, éppolyan absztrakt, mint egy huszadik századi rendszerváltás, politikai modellváltás soktényezős leírása. A mai Dél-Afrika területén élő bantu nyelvű népek, akik a későbbi Zulu államot, királyságot alkották, Max Gluckmann etnográfiája szerint a tizenötödik században vándoroltak e földekre. A tizennyolcadik század végére a korábbi pásztorkodó, szétszórt, nagycsaládos házközösségekben élő törzsek között a korábbi, főként szarvasmarha-portyákból álló hadviselés megváltozott és az effektív összecsapások, terület vagy törzs fennhatóságáért folytatott küzdelmek vették át a helyét.

A kisebb törzsi királyságok közötti konfliktusokból került ki győztesen Shaka, a zulu nép főnöke, aki behódoltatva, egyesítve a többi nemzetséget, létrehozta a Zulu államot. A különféle törzsekből nemzetet szervezett, a párhuzamokat kereső korabeli európai utazók és későbbi történészek személyét Napóleon Bonaparte alakjához és tetteihez mérték. „Fö érdeklődése a hadsereg felé fordult, és embereiből teljes időben katonáskodó harcosokat képzett; meghonosította a különböző korcsoportú férfiak külön szakaszokba szervezését, akiket egész évben barakkokban szállásolt el, az ország más-más pontjain”.? A különálló, rokonság alapján szer-

8 Turnbull 2005:7

9 Gluckmann 1950:26 veződő csoportokból tehát egy militáns, katonai expanzióra épülő államalakulatot épített, aminek megkérdőjelezhetetlen vezetőjévé vált. Egészen addig, amíg valamely testvére megelégelve bátyja zsarnokoskodását megmérgezte Shakát, hogy végül ő is (zulu fogalmak szerinti) zsarnokká legyen, és hasonlóképpen erőszakos halált haljon.

Ebben az esetben máig nem határozható meg világosan, teljes bizonyossággal, hogy miféle hatóokok állhattak a háborúzás módozatának megváltozása mögött, ami lehetővé tette egy erőskezű vezető kiemelkedését a törzsfők közül, aki a teljes addig létező társadalmi struktúrát erővel megváltoztatta, átszervezte. Talán nem jár messze az igazságtól az az elmélet, hogy a változás egyik legfontosabb eredője a populáció hirtelen megnövekedése volt. Mindenesetre Shaka a rendelkezésére álló erőforrásokból egy gyökeresen új rendszert épített, ami egy ideig a brit gyarmatosítókkal is képes volt dacolni.

\section{Innováció az információs társadalomban}

A big data fogalmáról, vagy a hozzá kapcsolódó társadalmi gyakorlatokról, gondolkodásmódokról elmélkedve felmerül a definiálás, kényszere és problémája, miképpen adható működő, társadalomtudományos eszközrendszerrel is használható értelmezése a divatos szónak. Min Chen és szerzötársai Big Data. Related Technologies, Challenges and Future Prospects című kötetükben külön fejezetet szenteltek a big data-t különféleképpen definiálni próbáló kísérleteknek. Az értelmezés egyik iránya egyfajta minimum definícióját adja meg a fogalomnak, mely szerint „olyan adathalmaz, amit nem lehet összegyüjteni, tárolni, kezelni a szokásos adatbázisokkal". ${ }^{10}$

Egy másik definíció a big data jellemzőiként a négy V-t határozza meg, azaz a Volume, Variety, Velocity, Value fogalmait. A Volume, a nagy menynyiséget emeli ki, mint meghatározó jellemzőt, a Variety a változó modalitást, jelleget hangsúlyozza, míg a Velocity az adatok gyors termelődését, a Value pedig az adatok értékét. ${ }^{11} \mathrm{Ez}$ a megközelítés népszerű, hiszen kiemeli az adatokban rejtőző értéket. Az újítás, innováció és normaszegés kapcsolatát körüljárni próbáló témám szempontjából kulcsfontosságú meglátás a Mayer-Schönberger \& Cukier szerzőpáros könyvében megfogalmazott gondolat,

10 Chen et al. 2014:2-3

11 Chen et al. 2014:4 
ami hangsúlyosan kiemeli, hogy a big data jelensége nem pusztán a technológia következménye (éppen úgy, mint a fentiekben említett japán taktikai újítás). A digitalizáció folyamata és a technikai feltételek változása, fejlődése értelemszerűen elősegítik nagy adatmennyiség összegyüjtését és felhasználását, ám, hogy ez utóbbi miként történik, már az elemző, vizsgálódó ember gondolkodásán, kreativitásán múlik, azon, hogy miképpen tud az addigi rendszerektől különböző ötlettel elöállni.

Mayer-Schönberger és Cukier példái Maury parancsnok és Koshimizu professzor történetein keresztül rávilágítanak arra, hogy bár a hajózást biztonságosabbá tehető adatok megvoltak az Egyesült Államok tengerészeti szerveinél, vagy a technológia már lehetővé tette, hogy az autóban ülő személy pozíciója, súlya, számos egyéb jellemzője alapján nyert adatok felhasználásával olyan rendszereket hozzanak létre, melyek megelőzhetnek baleseteket, megakadályozhatnak büncselekményeket, ezek megvalósítása teljesen újszerű gondolkodásmódot kívánt.

Gondolkodásmódok különbségét vizsgálja Peter Diamandis és Steven Kotler Bold címủ kötetükben, melyben első példájuk ismét rámutat az innováció és technológia kapcsolatára. George Eastman, a későbbi Kodak vállalat atyja ráébredve arra, hogy milyen üzleti lehetőségek rejlenek a fényképezés népszerűvé és elérhetővé tételében, megalapozta vállalata nagyjából egy évszázados sikerét. Ennek eléréshez értelemszerüen szükség volt a technika egyszerűsítésre, hétköznapi kezelhetőségére, ám a lényegi mozzanat mégis az a meglátás volt, ahogyan Eastman felismerte a technológia mögött meghúzódó, pillanatok megörökítésére irányuló vágyat.

Ugyanakkor a Kodak volt az a vállalat, ami nem volt képes felmérni a digitális fényképezésben rejlő lehetőségeket, így erre a felfedezésre ráillik a „nagy innováció” fogalma, hiszen ennek egyik eleme éppen az előreláthatatlanság, megjósolhatatlanság tényezője. Így amikor Sasson bemutatta találmányát, a cég vezetői nem ismerték fel az őket fenyegető válságot, krízist, ami, ha hosszútávon is, de elsöpri a fotózás klasszikus eszközeit, formáit. Ebből következik a szerzőpáros megállapítása, hogy az exponencialitás jelenségének hat fázisa közül (6 D) a digitalizáció lépése után a megtévesztés (deception) periódusa következik. A turneri kerethez visszatérve ez azt jelenti, hogy az egyik fél (a hatalom, a nagyvállalat) nem feltétlenül képes észlelni, azt, hogy egy, az addigi pozícióját fenyegető innováció (a normaszegés, törés momentuma) jelent meg.
A harmadik lépcsőfok a bomlasztás, megzavarás, szétzúzás szakasza. Ekkor az innováció örvén újonnan létrejött piac negatívan befolyásolja a már meglevő piacokat, vállalatokat, ezt tehát a válság állapota, a nyílt konfliktus kezdete. Az erre adott válaszok, a helyreállító akciók lehetnek, újításra tett kísérletek, üzleti ajánlatok. Diamandis és Kotler szemléletes példáját idézi egy lehetséges helyreállító akciónak, az Instagram felvásárlását a Facebook által. Amennyiben efféle feloldása nincs a krízis helyzetének, lehetséges végpont a „klasszikus” piac összeomlása és az újdonság, az innováció teljes térnyerése, ahogyan az a Kodak és a digitális fotózás történetéből látható.

\section{Digitális antropológia mint tudományos normaszegés?}

A megváltozott környezet, az új platformok, virtuális valóságok, kommunikációs terek és csatornák, szükségszerủen befolyásolják a különféle társadalmi életvilágokat feltárni igyekvő társadalomtudósokat. A fentiekben röviden felvázolt változások, új technológiák és gyakorlatok nem csupán a kvantitatív módszerekkel dolgozó kutatók munkáját, elméleti kereteit és módszertani megfontolásait érintik. Éppen így új terepek felfedezésére, vagy egyáltalán figyelembe vételére, és a hagyományos eszközök, technikák átdolgozására késztetett, késztet kvalitatív kutatásokat végző társadalomtudósokat, köztük kulturális antropológusokat.

A kulturális antropológia egyik alappillérének, legfőbb módszertani elvének, az állomásozó terepmunkának első gyakorlója és kigondolója, Bronislaw Malinowski a diszciplína mai szabályainak megalkotója, mitikus őse, alapító atyja olyan keretet teremtett, ami klasszikussá vált Trobriandszigeteki kutatása után száz évvel is nagy vonalaiban érvényes. Az általa megfogalmazott javaslatok, szempontok és a "jó terepmunka” első leírása, a huszadik század eleje óta segíti, befolyásolja, adott esetben hátráltathatja az antropológiai, etnográfiai kutatások tervezését. A hosszú (legalább fél, vagy inkább egy éves) ottlét, mint a későbbi munkát, elemzést legitimáló egyik tényezo, a „bennszülöttek" közötti életmód gyakorlása, részvétel a közösség hétköznapi létezésben, „a való élet és a tipikus viselkedés apró részleteinek megfigyelése" ${ }^{12}$ mindmind az ő öröksége.

12 Malinowski 2000:54 
Sok esetben az általa felállított mérce, vagy talán pontosabban a sokféle külső körülmény által alakított terepmunkájának a tudományos közösség általi intézményesítése, máig követelmény a kulturális antropológia akadémiai szintű művelésében. Értelemszerüen ez nem azt jelenti, hogy pontosan ugyanazokkal a módszerekkel dolgozna egy terepmunkát végző kulturális antropológus, mint elődei egy évszázaddal ezelőtt, ám a résztvevő megfigyelés alapvető szabályai, az érvényes antropológiai munka kritériumai nem változtak meg gyökeresen. Különböző társadalomtudományi határterületek elméletei és módszerei hatottak az antropológia diszciplínájára, egyes filozófiai irányzatok megtermékenyítóleg érintették a tudományág gondolkodásmódját, problematizálták a kutató, a tudás az értelmezés és a terep fogalmait. Ám egy viszonylag mai, a huszadik század második felének elméleti és módszertani változásait figyelembe vevő 2005-ös tankönyv, Michael V. Angrosino Doing Ethnographic and Observational Research címủ kötetében az etnográfiai módszer rövid ismertetésekor a következő fö pontok olvashatók: terephez kötött (emberek által lakott élt, térben zajlik), perszonalizált (személyes jelenlét és találkozás, ezáltal résztvevővé válás), hosszútávú, induktív, holisztikus, dialogikus.

Ahhoz, hogy a digitális antropológia, digitális etnográfia bekerülhessen a diszciplína már elfogadott témái, módjai közé, a virtuális, online térben végzett résztvevo" megfigyelésnek is hasonló módon legitimmé kellett válnia, mint a fél évszázada szintén úttörőnek számító saját közösség-kutatások, vagy a városi csoportok antropológiai nézőpontú kutatása, melyek szintén szakítottak a klasszikusnak számító állomásozó terepmunka koncepciójával. Többek között ki kellett terjeszteni az Angrosino által is megfogalmazott alapvető kívánalmakat. Kiváló példa erre a személyes találkozás dilemmája, hiszen egyes online platformokon valóban személyek találkoznak ugyan, de egy közvetítő közegen keresztül. ${ }^{13}$

Azt, hogy a terepmunka szigorúan értelmezett módszerét sikerült elfogadtatni a szélesebb antropológus közösségben, és ezzel teret kapott a digitális antropológia aldiszciplínája, jól jelzi, hogy az American Anthropological Association szervezetén belül 2012-ben megalakult a Digital Anthropology Interest Group. Ugyanakkor a további legitimáció fontosságát, a kutatási irányok, elméleti megfontolások és alkalmazott módszerek megismertetését, presztízsének növelését fontosnak tartja ez a csoport

13 Pink et al 2016:3 is. Ennek egyik általuk megjelölt eszköze, egy listaszerű, ötletelő felsorolásban többek között éppen a tradicionális módszertanok bevonása, alkalmazása, a meglevő kutatásokkal való párhuzamba állítás, pontosabb etikai szabályok megalkotása. ${ }^{14}$

Ugyanakkor a legitimáció kézenfekvő módja olyan kutatások véghezvitele és prezentálása, ami egyszerre igazolja a klasszikus módszerek alapján dolgozó új módszertanok hasznát és rámutat a kutatott új világok, virtuális terek elemzésének hasznára és létjogosultságára. Ezt a szerepet tölti be például Bonnie Nardi My Life as a Night Elf Priest címü könyve, ami World of Warcraft kulturális antropológia vizsgálatát beszéli el. Ebben a szerző egyfelől résztvevő megfigyelője az online szerepjáték egy karakterének bőrében a játék világának, így a hagyományos módszert alkalmazza egy új térben, míg kutatásának másik pillére a játékosokkal az USA-ban és Kínában készített interjúk. ${ }^{15}$ Ezzel a munkájával belülről képes láttatni a World of Warcraft világát, beszélgetései nyomán megdőlnek sztereotípiák (például, hogy az átlagos játékos a befelé forduló, kapcsolatokat nehezen teremtő fiatal férfi). ${ }^{16}$

A kulturális antropológia világán belül, tehát ismét megváltozhatott a terep éppen úgy, mint a huszadik század hatvanas éveiben, amikor az „egzotikus”, „vad” világok helyett saját társadalmaik közösségeiben lelték meg a kutatni lehetséges és érdemes csoportokat. Az eszközök is értelemszerüen idomultak, idomulnak az új közegekhez, új létmódokhoz, ám a módszertani alapvetések, a vizsgálni vágyott emberi történetek és azok értelmezésére tett kísérletek maradni látszanak.

\section{Felhasznált irodalom}

Arendt, Hannah 1991 A forradalom. Budapest, Európa Könyvkiadó.

Chen, Min \& Leung, Victor C. M. \& Mao, Shiwen \& Zhang Yin 2014 Big Data. Related Technologies, Challenges and Future Prospects. New York, Springer.

Diamandis, Peter \& Kotler, Steven 2015 Bold. How to Go Big, Create Wealth and Impact the World. New York, Simon \& Schuster.

14 https://01 anthropology.wordpress. com/2012/11/20/cyberworlds-digital-studiesopenthread/

15 Nardi 2010:7

16 Nardi 2010:18 
Gluckman, Max 1950 The Kingdom of the Zulu of South Africa. In Evans-Pritchard, Edward Evans - Fortes, Meyer szerk. African Political Systems. London, Oxford University Press, 25-55.

Hofer Tamás 1992 Harc a rendszerváltásért szimbolikus mezőben. Politikatudományi Szemle 1. évf. 1. szám

Holczer Márton 2007 Innovációs verseny az információs társadalomban. In Pintér Róbert szerk. Az információs társadalom: az elmélettól a politikai gyakorlatig. Budapest, Gondolat Kiadó, Új Mandátum Kiadó, 94-113.

Kövér György 2011 A tiszaeszlári dráma. Budapest, Osiris Kiadó.
Mayer-Schönberger, Viktor \& Cukier, Kenneth 2013 Big Data. A Revolution That Will Transform How We Live, Work and Think. London, John Murray.

Nardi Bonnie 2010 My Life as a Night Elf Priest. USA, University of Michigan Press.

Pink, Sarah \& Horst, Heather \& Postill, John \& Hjorth, Larissa \& Lewis, Tania \& Tacchi Jo 2016 Digital Ethnography. Principles and Practice. London, Sage Publications.

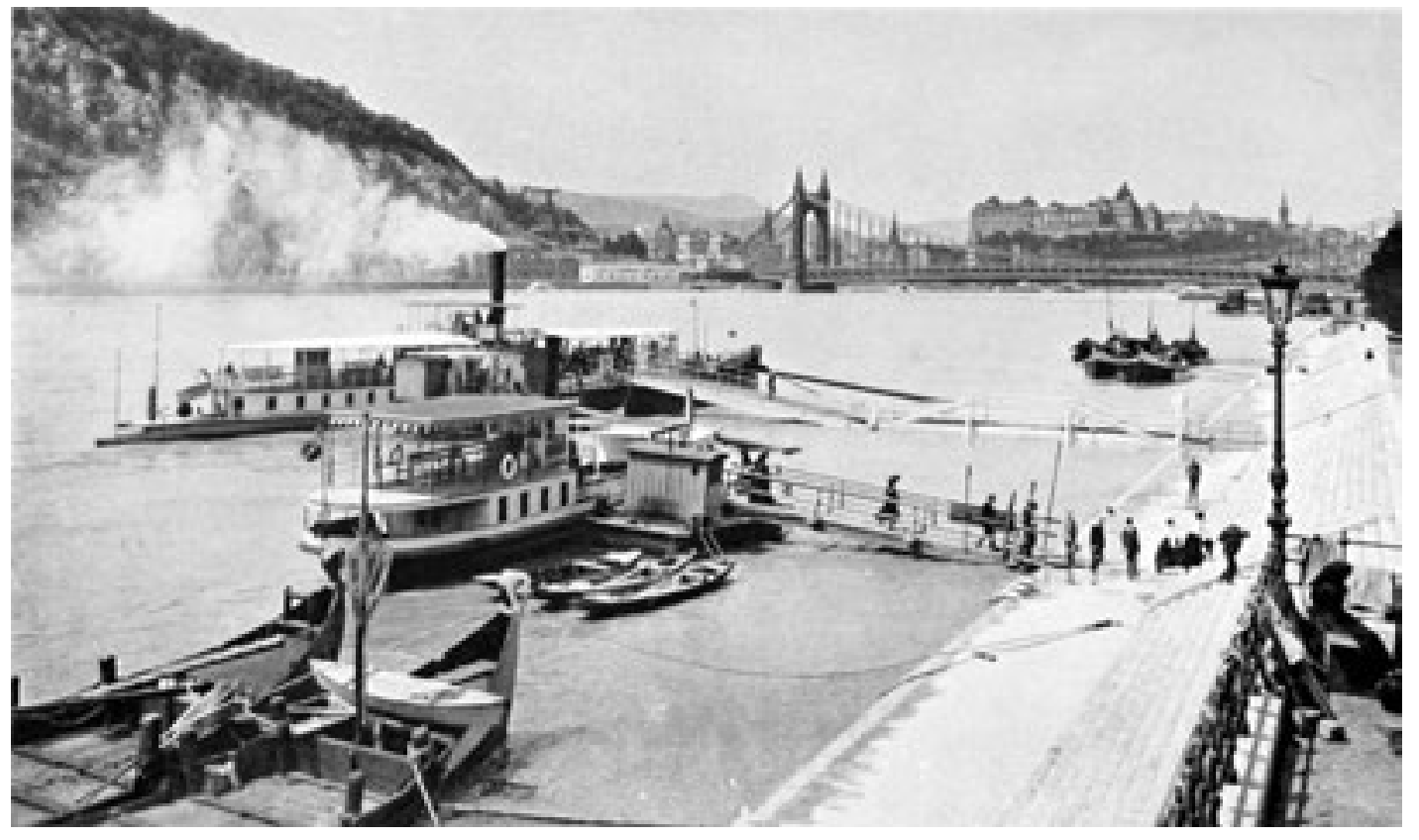

